\title{
AKTIVITAS ANTIINFLAMASI EKSTRAK DAUN UBI JALAR (Ipomoea batatas Poir.) TERHADAP TIKUS PUTIH (Rattus norvegicus)
}

\author{
Alas Setiawati*, Victoria Yulita Fitriani, Muhammad Amir M \\ Laboratorium Penelitian dan Pengembangan FARMAKA TROPIS, Fakultas Farmasi Universitas Mulawarman, \\ Samarinda, Kalimantan Timur \\ *Corresponding author email: iiaa_jf@yahoo.co.id
}

\begin{abstract}
According to empirical sweet potato leaves can be efficacious as antiinflammation, and therefore this research aims to obtain an effective concentration of extracts as antiinflammation. Research is done tested the antiinflammation effect of sweet potato leaf extracts by topically to mouse (Rattus norvegicus). Where carragenan used as induced croupous and croupous formed measured by pletismometer, The results obtained is that sweet potato leaf extracts has antiinflammation effect, whitch at concentration of $30 \%, 60 \%$, and $90 \%$, respectively indicate the presence of antiinflammation activity. Indicates exctract of sweet potato own an activivity to antiinflannation.
\end{abstract}

Keywords : Sweet potato (Ipomoea batatas Poir), Antiinflammation

\begin{abstract}
ABSTRAK
Menurut empiris daun ubi jalar dapat berkhasiat sebagai antiinflamasi, maka dari itu Penelitian ini bertujuan untuk mengetahui konsentrasi yang paling baik dari daun ubi jalar sebagai antiinflamasi. Pengujian dilakukan secara topikal dengan menggunakan hewan uji tikus (Rattus norvegicus). Dimana karagenan digunakan sebagai penginduksi radang dan radang yang terbentuk diukur dengan pletismometer. Hasil penelitian yang didapatkan adalah ekstrak daun ubi jalar memiliki efek antiinflamasi, dimana pada konsentrasi 30\%, 60\%, dan $90 \%$ masing-masing menunjukkan adanya aktivitas antiinflamasi. Hasil pengujian tersebut maka diperoleh hasil bahwa daun ubi jalar memiliki aktivitas sebagai antiinflamasi.
\end{abstract}

Kata Kunci : Daun Ubi Jalar (Ipomoea batatas Poir), Antiinflamasi

Submitted on: 5 January $2017 \quad$ Accepted on: 15 February 2017

DOI: https://doi.org/10.25026/jsk.v1i6.68

\section{PENDAHULUAN}

Kalimantan Timur sendiri kaya akan berbagai keanekaragaman hayati yang berpotensi untuk dikembangkan sebagai obat atau bahan baku obat. Hal tersebut menunjukkan besarnya peran dan potensi bahan alam dalam proses pencarian dan pengembangan bahan obat. Beragam tanaman yang dipercaya berkhasiat sebagai bahan pengobatan namun belum ada pengkajian lebih dalam tentang khasiat dari tanaman tersebut. Salah satu tumbuhan yang masih digunakan dalam pengobatan alternatif yakni daun ubi jalar, dimana masyarakat khususnya daerah Samarinda masih menggunakan daun ubi jalar yang dipercaya sebagai pengobatan inflamasi atau radang. Berkat dari data empirik yang ada dimasyarakat oleh karenanya peneliti tertarik untuk melakukan pengkajian lebih lanjut mengenai efek antiinflamasi dari daun ubi jalar.

Proses gejala dari terjadinya inflamasi salah satunya adalah bengkak. 
Secara empiris tanaman daun ubi jalar memiliki khasiat menyembuhkan bengkak. Berawal dari hal tersebut maka daun ubi jalar dapat berefek sebagai antiinflamasi. Dalam penelitian-penelitian disebutkan kandungan dari tanaman yang berkhasiat sebagai antiinflamasi adalah flavonoid (Kohli, 2005).

Ubi Jalar (Ipomoea batatas Poir) atau yang sering disebut dengan ketela rambat adalah sejenis tanaman yang akarnya dapat dimakan. Asal ubi jalar diperkirakan dari benua Amerika. Di beberapa daerah tertentu, ubi jalar merupakan salah satu bahan makanan pokok. Di Indonesia, selain dimanfaatkan umbinya, daun ubi jalar juga dibuat sayuran. Untuk dibeberapa wilayah daun dari rebusan ubi jalar diminum dan digunakan sebagai pengobatan DBD, antioksidan, antikanker dan dapat juga ditumbuk dan ditempelkan pada bagian yang bengkak sebagai pengobatan inflamasi/radang (Agoes 2007).

Salah satu tumbuhan obat tradisional adalah ubi jalar (Ipomoea batatas Poir) dari family Convolvulaceae. Tumbuhan ubi jalar yang akan digunakan adalah daun ubi jalar yang mengandung beberapa senyawa seperti flavaonoid, saponin dan polifenol. Dari kandungan senyawa tersebut dapat berkhasiat sebagai antiinflamasi, anti kanker, obat demam berdarah, dan obat diabetes melitus (Dalimarta, 2011)

Inflamasi merupakan suatu respon protektif normal terhadap luka jaringan yang disebabkan oleh trauma fisik, zat kimia yang merusak, atau zat-zat mikrobiologik. Inflamasi adalah usaha tubuh untuk menginaktifasi atau merusak organisme yang menyerang, menghilangkan dan mengatur derajat perbaikan jaringan (Mycek, 2001).

\section{METODE PENELITIAN}

Metode pengujian aktivitas antiinflamasi dilakukan berdasarkan pada kemampuan sampel uji dalam mengurangi atau menekan radang yang terbentuk pada hewan uji. Pada pengujian ini digunakan metode induksi menggunakan larutan iritan pembentuk radang, yaitu karagenan $1 \%$ yang diinduksikan secara intra plantar pada telapak kaki tikus.

\section{Alat dan Bahan}

Peralatan yang digunakan dalam penelitian ini antara lain peralatan pengambilan sampel, stopwatch, rotary evaporator, gelas kimia, labu ukur, botol selai, waterbath, batang pengaduk, pipet tetes, pinset, timbangan analitik digital, penangas air, selang plastik, spoit, dan pletismometer.

Bahan yang digunakan dalam penelitian ini antara lain daun ubi jalar (Ipomoea batatas Poir) pelarut metanol berfungsi sebagai pelarut, tikus jantan dengan berat rata-rata 18-40 gram berfungsi sebagai hewan uji, karagenan berfungsi sebagai bahan penginduksi, dan larutan fisiologis $\mathrm{NaCl} \mathrm{0,9 \% .}$

\section{Prosedur Pengujian Penelitian}

Pengujian aktivitas antiinflamasi ekstrak daun ubi jalar terhadap tikus putih. Disiapkan tikus putih sebanyak 21 ekor kemudian sebelum diberikan larutan karagenan diukur terlebih dahulu ukuran kaki tikus normal dengan menggunakan pletismometer, setelah itu diberi larutan karagenan dengan cara disuntikan dibawah telapak kaki tikus, kemudian didiamkan selama 30 menit. Bengkak yang terbentuk pada kaki tikus diukur kembali dengan menggunakan pletismometer. Kemudian diberi ekstrak daun ubi jalar dengan konsentrasi 30\%, 60\%, dan $90 \%$. 
Pengukuran dilakukan dengan selang waktu 30 menit selama 2 jam.

\section{HASIL DAN PEMBAHASAN}

\section{Konsentrasi Efektif Daun Ubi Jalar Sebagai Antiinflamasi}

Konsentrasi efektif ekstrak didapat dari data hasil kemampuan ekstrak dalam menurunkan radang yang terbentuk. Sehingga konsentrasi yang paling baik dalam menurunkan radang yang digunakana sebagai konsentrasi efektif. Hasil pengujian variasi konsentrasi ekstrak daun ubi jalar dapat dilihat pada tabel 1 .

Tabel 1 menunjukkan bahwa pada konsentrasi $30 \%$ terjadi penurunan radang di menit 60 dan terus menurun di menit 90 , 120, dan 150 menit. Sedangkan pada konsentrasi $60 \%$ dan $90 \%$ penurunan radang terjadi dimenit 90, 120, dan 150 menit. Maka dapat disimpulkan bahwa konsentrasi 30\% memiliki kemampuan yang lebih cepat dalam menurunkan radang.

Adanya penurunan radang yang terjadi, diduga karena adanya flavanoid yang telah tersari dalam ekstrak daun ubi jalar. Karena flavanoid secara umum mempunyai kemampuan penghambatan enzim siklooksigenase dan lipooksigenase. Pembengkakkan ini yang mengakibatkan radang kaki tikus menurun.

Tabel 1 Nilai Penurunan Radang Variasi Konsentrasi

\begin{tabular}{cccccc}
\hline \multirow{2}{*}{ Perlakuan } & \multicolumn{5}{c}{ Nilai Rata-Rata Pada Waktu t menit (mL) } \\
\cline { 2 - 5 } & 30 menit & 60 menit & 90 menit & 120 menit & 150 menit \\
\hline K30\% & 0 & 0,001 & 0,002 & 0,003 & 0,004 \\
K60\% & 0 & 0 & 0,001 & 0,003 & 0,004 \\
K90\% & 0 & 0 & 0,001 & 0,002 & 0,004 \\
Kontrol Negatif & 0 & 0 & 0,001 & $-0,001$ & $-0,001$ \\
\hline
\end{tabular}

Keterangan: K30 : Konsentrasi $30 \%$

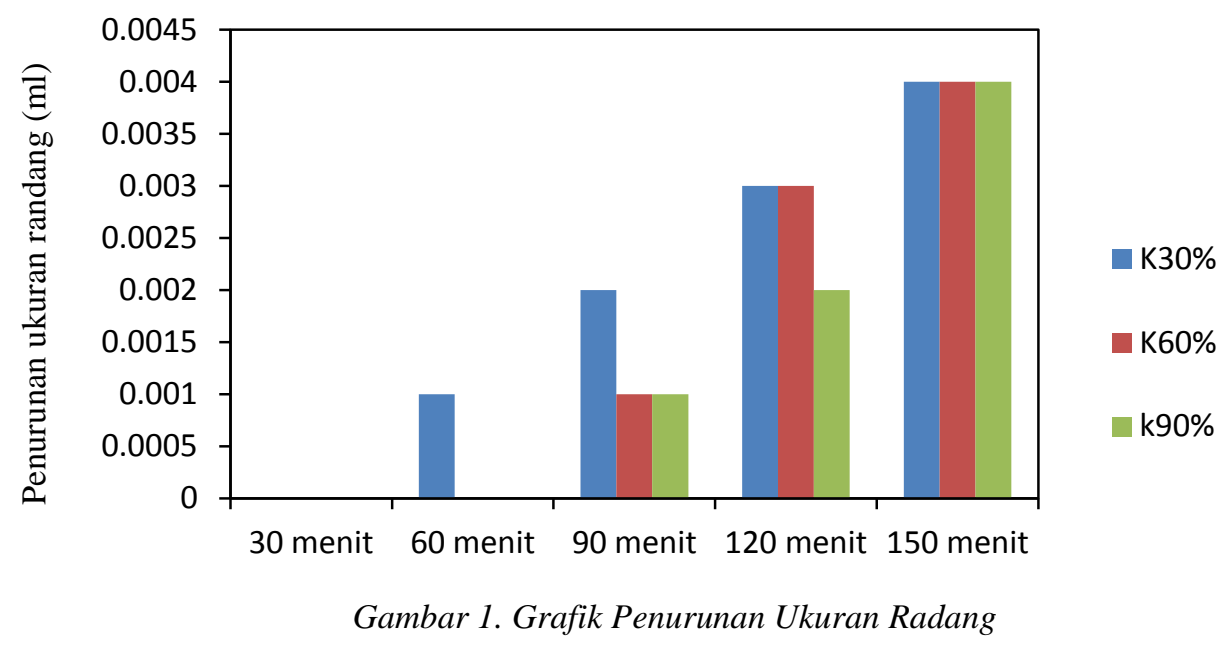


Gambar 1 menunjukkan bahwa pada setiap variasi konsentrasi ekstrak daun ubi jalar memberikan penurunan radang yang berbeda-beda. Adanya perbedaan penurunan radang dari masingmasing konsentasi ini diduga karena adanya perbedaan tingkat kelarutan ekstrak, maupun adanya perbedaan variasi mekanisme respon dari tubuh tikus putih. Penurunan radang terbesar dari variasi konsentrasi uji yaitu pada konsentrasi $30 \%$.

Analisis varian 2 arah dan uji lanjutan sesuai dengan nilai koefisien keseragaman (KK) dilakukan untuk mengetahui adanya perbedaan pengaruh tiap perlakuan serta mengetahui konsentrasi yang paling efektif hasil perhitungan anova 2 arah dapat dilihat pada tabel 3.

Berdasarkan tabel 3 diatas dapat diamati bahwa nilai $\mathrm{F}$ hitung 5,5 lebih besar daripada nilai Ftabel (5\%) yaitu 2,80 maka dapat disimpulkan bahwa variasi konsentrasi ekstrak memberikan pengaruh yang berbeda nyata dan dapat menurunkan radang pada telapak kaki tikus putih.
Pada data variasi waktu dapat diketahui bahwa nilai Fhitung 8,5 lebih besar dibandingkan dengan nilai Ftabel (5\%) 2,56. Maka dapat disimpulkan bahwa interval waktu memberikan pengaruh yang berbeda nyata dalam menurunkan radang pada telapak kaki tikus putih.

Sedangkan pada data variasi interaksi, yaitu antara variasi konsentrasi dengan variasi interval waktu dalam menurunkan pembengkakan, untuk nilai Fhitung 0,1 lebih kecil dibandingkan dengan nilai Ftabel (5\%) 1,96. Maka dapat disimpulkan bahwa interaksi antara konsentrasi dan interval waktu tidak memberikan perbedaan nyata dalam menurunkan radang pada telapak kaki tikus.

$$
\text { Uji dilanjutkan dengan }
$$
menggunakan BNJD (Beda Nyata Jujur Ducan) dengan nilai koefisien keseragaman (KK) yaitu $75,49 \%$ untuk koefisien konsentrasi dan 32\% untuk koefisien waktu dapat dilihat pada tabel 4 .

Tabel 3 hasil perhitungan anova 2 arah

\begin{tabular}{cccccc}
\hline $\begin{array}{c}\text { Sumber } \\
\text { variasi }\end{array}$ & $\begin{array}{c}\text { Jumlah } \\
\text { Kuadrat }\end{array}$ & $\mathrm{db}$ & $\begin{array}{c}\text { Kuadrat } \\
\text { Tengah }\end{array}$ & Fhitung & Ftabel \\
\hline Kons. & 0,00035 & 3 & 0,00011 & 5,5 & $5 \%$ \\
waktu & 0,00007 & 4 & 0,00002 & 8,5 & $2,50^{*}$ \\
Interaksi & 0,00003 & 12 & 0,000002 & 0,1 & $1,96^{* *}$ \\
Galat & 0,00070 & 48 & 0,00002 & & \\
Total & 0,00115 & 67 & & & \\
\hline
\end{tabular}

Tabel. 4 BNJD (Beda Nyata Jujur Ducan) konsentrasi

\begin{tabular}{cccccc}
\hline & Perlakuan & Air & $90 \%$ & $30 \%$ & $60 \%$ \\
\cline { 2 - 6 } BNJD & Air & - & & & \\
Untuk & $90 \%$ & $0,005: 0,0043$ & - & - & \\
0,05 & $60 \%$ & $0,006: 0,0045$ & $0,001: 0,0043^{*}$ & $0,001: 0,0043^{*}$ & - \\
\hline
\end{tabular}


Tabel. 5 BNJD (Beda Nyata Jujur Ducan) waktu

\begin{tabular}{|c|c|c|c|c|c|c|}
\hline \multirow{6}{*}{$\begin{array}{c}\text { BNJD } \\
\text { Untuk } \\
0,05\end{array}$} & Perlakuan & 30 menit & 60 menit & 90 menit & 120 menit & 150 menit \\
\hline & 30 menit & - & & & & \\
\hline & 60 menit & $0,001: 0,0043^{*}$ & - & & & \\
\hline & 90 menit & $0,002: 0,0045^{*}$ & $0,001: 0,0043^{*}$ & - & & \\
\hline & 120 menit & $0,003: 0,0046 *$ & $0,002: 0,0045^{*}$ & $0,001: 0,0043 *$ & - & \\
\hline & 150 menit & $0,004: 0,0048 *$ & $0,003: 0,0046^{*}$ & $0,002: 0,0045^{*}$ & $0,001: 0,0045^{*}$ & - \\
\hline
\end{tabular}

Keterangan: $*=$ Signifikan,

$* *=$ Sangat Signifikan

Berdasarkan tabel 4 dapat disimpulkan bahwa variasi konsentrasi yang paling baik dalam menurunkan radang adalah pada konsentrasi 30\%. Hal diduga dipengaruhi oleh tingkat dimana kelarutan ekstrak di konsentrasi 30\% sudah seimbang. Selanjutnya tingkat kelarutan ekstrak pada konsentrasi $60 \%$ dan $90 \%$ rendah bisa terjadi karena terlalu banyak ekstrak sehingga susah untuk larut dan air maka air tidak memiliki aktivitas dalam penurunan radang.

Berdasrkan tabel 5 dapat disimpulkan bahwa dari waktu yang paling baik dalam menurunkan radang secara berturut-turut adalah pada waktu 150 menit, lalu pada waktu 120 menit, kemudian pada waktu 90 menit, dan yang terakhir adalah pada waktu 60 menit karena pada waktu 150 menit merupakan waktu yang paling maksimal dalam menurunnya nilai radang dibandingkan dengan waktu lainnya. Maka disimpukan bahwa 150 adalah waktu yang terbaik dalam menurunkan radang.

\section{KESIMPULAN}

Ekstrak daun ubi jalar (Ipomoea batatas Poir) memiliki konsentrasi efektif sebagai antiinflamasi paling baik yang ditinjau dari tiap interval waktunya adalah pada konsentrasi 30\% kemudian $60 \%$ dan yang terakhir $90 \%$, dengan waktu 60 menit, 90 menit, 120 menit dan 150 menit.

\section{UCAPAN TERIMA KASIH}

Peneliti menyampaikan ucapan terima kasih kepada saudari Eka Novianda S.Farm yang telah bersedia bekerja sama tentang penelitian daun ubi jalar ini.

\section{DAFTAR PUSTAKA}

[1]. Agoes, G. 2007. Teknologi Bahan Alam. Bandung : Penerbit ITB.

[2]. Dalimartha, S. 2000. Atlas Tumbuhan Indonesia Jilid 2 dalam Nurul Fauziyah. Efek Antiinflamasi Ekstrak Etanol Daun Petai Cina (Leucaena glauca, Benth) Pada Tikus Putih Jantan Galur Wistar, Skripsi. Surakarta : Universitas Muhammadiyah Surakarta.

[3]. Kohli, K., Ali J., Ansari M. J., and Raheman Z. (2005). Curcumin : A Natural Antiinflamamatory Agent, in Indian Journal of Pharmacology. New Delhi : Jarnia Hamdard University. Pages. 141- 142

[4]. Mycek, M.J., Harver, R.A., Champe, P.A. 2001. Farmakologi Ulasan Bergambar edisi kedua. Jakarta : Penerbit Widya Medika. 